\title{
Analysis of Student's Creativity Value and Process Skills through Learning Strategies Guided Inquiry
}

\author{
Muchsin $^{1}$, Hamdi $^{2}$ \\ ${ }^{1}$ Muchsin, is a Lecturer of Universitas Jabal Ghafur Sigli, Indonesia \\ Email: muchsin@unigha.ac.id \\ ${ }^{2} \mathrm{Hamdi}$, is a Lecturer of Universitas Jabal Ghafur Sigli, Indonesia \\ Email: hamdi@unigha.ac.id
}

\begin{abstract}
This study aims to analyze the effect of learning with guided inquiry strategies on creativity and science process skills at SMA Negeri 1 Bandar Baru. This research uses a quantitative descriptive approach with quasi experimental research techniques. The design used in this study was a non-equivalent control group design. Data collection was grouped into 2 groups, namely the experimental group and the control group. The number of samples in this study were 50 students for the experimental class and 52 students for the control class. The research instruments were creativity tests and science process skills tests. The value of the students' creativity test results at a significance level of 0.05 obtained that the sig value was 5.965> 1.98 (tcount $>$ ttable) and Sig (2-tailed) $0.000<0.05$ indicating that the data was significant or significantly different between the experimental class and the class control. Hypothesis testing with the SPSS version 23.0 for windows program at a significant level of 0.05 was obtained; The value of students 'science process skills shows that $t$-count $>\mathrm{t}$-table at a significant level of 0.05 , namely 6.055 $>1.98$, indicates that there is an effect of guided inquiry strategies on students' science process skills. This shows that the science process skills of students who have a high level of creativity with students who have a low level of creativity, where students who have a high level of creativity obtain higher process skills than students who have a low level of creativity and between students' creativity and science process skills.
\end{abstract}

Keywords: guided inquiry, creativity, science process skills

\section{INTRODUCTION}

The material in physics in high school (SMA) has abstract material characteristics, one of which is because it relates to complex physical and chemical mechanisms. This mechanism causes students to have difficulty understanding process skills which are closely related to the mechanism of electricity formation and delivery. Though this material is very important because it relates to other concepts, especially about electrodynamics Mudalara (2012).

Physics learning is still dominated by the behavioristic paradigm which considers knowledge as facts that must be memorized and the teacher as the main source of knowledge. In this paradigm, teachers do not involve students much in learning such as 
not teaching students in groups, not doing group inquiry, not involving students in lesson planning, not conducting project assessments, not conducting group discussions, and not presenting discussion results to the class. Students' understanding of the subject matter will be realized if students themselves are directly involved in understanding the subject matter, for example by reading books, making conclusions, explaining verbally, asking, and answering questions. All of this can be done with group discussions and class discussions by paying attention to the differences between students so as to create a pleasant classroom atmosphere. This conducive atmosphere cannot be separated from the involvement of the teacher as a motivator and facilitator (Muchsin and Mariati 2020).

Students will master good concepts and principles if they have good scientific process skills. The success of students in understanding the subject matter, depends on the teacher as a guide who must act as a good motivator and facilitator (Muchsin and Mariati 2020). During the teaching and learning process, it is better to be actively involved in the teaching and learning process. This is reflected in the activities of students in learning not only as recipients of subject matter. Students' understanding of the subject matter will be realized, if the students themselves are directly involved in understanding the subject matter. Students are involved by reading books, making conclusions, explaining orally, asking questions, and answering questions. All of this can be done with group discussions and class discussions by paying attention to the differences between students so as to create a pleasant classroom atmosphere. This conducive atmosphere cannot be separated from the involvement of the teacher as a motivator and facilitator (Mulyasa, 2005). .

The fact can be seen by many students who consider learning physics difficult to understand, students are less involved in the teaching and learning process. This can be seen in the ongoing teaching and learning process, namely the lack of student learning activities and low learning outcomes. One of the reasons for the low learning outcomes is the teacher's factor in implementing learning strategies. Some teachers have not been able to develop student creativity in learning and are less than optimal in involving students in learning.

In accordance with the principle of education is a conscious effort (Abubakar \& Anwar, 2018), so the essence of science learning which refers to scientific processes, products and attitudes, learning electrical materials is ideally able to provide various learning experiences to understand scientific concepts and processes. Process skills include observing skills, proposing hypotheses, using tools and materials properly and correctly by always considering work safety and security, asking questions, classifying and interpreting data, and communicating findings verbally or in writing, digging and sorting relevant factual information for test ideas or solve everyday problems (Dahar, 2011).

Science process skills are complex sets of abilities commonly used by scientists in carrying out scientific investigations in a series of learning processes. Science process skills are a series of activities that can be measured from practicum activities. Practicum is the best means of developing process skills. Inquiry strategies can be realized through practicum activities (Rustaman, 2009).

Students will master good concepts and principles if they have good science process skills. The success of students in understanding the subject matter, depends on the teacher as a guide who must act as a good motivator and facilitator (Israwati, 2018). During the teaching and learning process, it is better to be actively involved in the teaching and 
learning process. This is reflected in the activities of students in learning not only as recipients of subject matter.

In this case, the teacher must be good at compiling learning scenarios. Learning that emphasizes the memorization method and looks for one correct answer must immediately be abandoned and switch to learning designs that allow students to express creativity and science process skills. Learning with a non-authoritarian atmosphere, where the teacher believes in the ability of students to think and has the courage to come up with new ideas and when students are given the opportunity to work according to their interests and needs, their creative abilities will flourish (Munandar, 2009). Student creativity in learning is highly dependent on teacher creativity in creating a conducive learning environment. Therefore, teachers can use various approaches in increasing student creativity (Mulyasa, 2010).

The success of the teaching and learning process is directly influenced by the strategies used by the teacher in teaching. Inquiry strategies provide opportunities for students to solve problems in learning independently. The use of inquiry strategies is expected to open students' insights to find concepts from working independently and in groups. Guided inquiry learning is a teaching strategy that allows students to move step by step from problem identification, defining hypotheses, problem formulation, data collection, verification of results, and generalization with drawing conclusions (Massialas, 2009).

The most widely used inquiry strategies are free inquiry and guided inquiry. Free inquiry is described as a student-centered approach. Students in this approach, form their own problems and hypotheses, make plans for scientific research, conduct this research to test their hypotheses and discuss their findings with other friends (Hassard, 2010). Guided inquiry requires a higher order of thinking. Through guided inquiry the teacher provides input for students with problems to investigate along with procedures and materials. This type of inquiry learning is used to teach a specific concept, fact or skill and lead a way to open up an inquiry in which students formulate their own problems to investigate.

Inquiry strategy is closely related to student creativity. The results showed that the inquiry strategy could improve scientific understanding, be productive in creative thinking and students became skilled in obtaining and analyzing information (Hassard, 2010). The aim of training process skills in science learning is to increase student motivation and learning outcomes, because in this training students are encouraged to participate actively and efficiently in learning, completing student learning outcomes simultaneously (Trianto, 2010).

Process skills include observing skills, proposing hypotheses, using tools and materials properly and correctly by always considering work safety and security, asking questions, classifying and interpreting data, and communicating findings verbally or in writing, digging and sorting relevant factual information for test ideas or solve everyday problems (Dahar, 2011).

Science process skills are complex sets of abilities commonly used by scientists in carrying out scientific investigations in a series of learning processes. Science process 
skills are a series of activities that can be measured from practicum activities, as the best means of developing process skills (Rustaman, 2005). Guided inquiry strategies can be realized through practicum activities.

Inquiry requires a higher order of thinking. Through inquiry the teacher provides input for students with problems to investigate along with procedures and materials. This type of inquiry learning is used to teach certain concepts, facts or skills and lead a way to open up an inquiry in which students formulate their own problems to investigate (Brickman, et. Al. 2009).

Students will master good concepts and principles if they have good scientific process skills. The success of students in understanding the subject matter, depends on the teacher as a guide who must act as a good motivator and facilitator. During the teaching and learning process, it is better to be actively involved in the teaching and learning process. This is reflected in the activities of students in learning not only as recipients of subject matter.

Munandar (1999) states learning with a non-authoritarian atmosphere, where the teacher has confidence in the ability of students to think and dare to come up with new ideas. When students are given the opportunity to work according to their interests and needs, their creative abilities will flourish.

The success of the teaching and learning process is directly influenced by the strategies used by the teacher in teaching. Inquiry strategies provide opportunities for students to solve problems in learning independently. The use of inquiry strategies is expected to open students' insights to find concepts from working independently or in groups.

The inquiry strategy is described as a learner-centered approach. Learners in this approach, form their own problems and hypotheses, make plans for scientific research, conduct this research to test their hypotheses and discuss their findings with other peers (Hassard, 2005). This type of inquiry learning is used to teach certain concepts, facts or skills and lead ways to open up investigations in which learners formulate their own problems to investigate, one of the concepts taught through inquiry strategies is growth and development.

Joyce \& Weil (2011) stated that inquiry strategies can improve understanding of science, be productive in creative thinking and students become skilled in obtaining and analyzing information. Trianto (2010) states that the goal of training process skills in science learning, especially in biology subjects, is to increase student motivation and learning outcomes, because the main objective of inquiry strategies is that students are encouraged to participate actively and efficiently in learning and complete student learning outcomes. students simultaneously.

The use of inquiry-based teaching methods in both classes, namely the experimental class and the control class. The experimental class has significantly improved students' science process skills and attitudes. Students in the experimental group had a better understanding of the concepts of acids and bases and a more positive attitude towards guided inquiry instruction (Remziye, at.al, 2011 \& Bilgin, 2009).

The results of his research, qualitative and quantitative findings indicate that the level of expectations of success of participants and expectation of outcomes at posttest scores is higher than pretest scores. This paper also presents the effectiveness of guided inquiry methods to increase the self-efficacy of pre-service teachers in teaching science 
(Özdilek, \& Bulunuz, 2009). Students who were instructed through inquiry-based learning achieved higher scores than those ordered through traditional methods (Abdi, 2014).

The statistical data shows that there is a significant difference between the pre-test and post-test mean scores of both the control and experimental groups; However, the mean score of the experimental group showed greater improvement compared to the control group. While findings derived from follow-up forms and teacher interview analysis suggest that the experimental process changed the resistance behavior of students in positive ways, these changes were not permanent at the end of the experimental process. As a result, it was found that students can have a variety of resistant behaviors and these behaviors can be positively influenced by different teaching methods that are accepted as effective in the discipline (Sever, \& Güven, 2014).

The effect of using guided inquiry through experimental and demonstration learning methods on increasing learning achievement. There are differences in cognitive learning achievement between students with guided inquiry learning methods and projects (Kholifudin, 2012 \& Deta, 2013).

Guided inquiry learning is very good because it can improve learning outcomes. Learning orientation with a guided inquiry strategy is an effective approach in improving student academic achievement during the learning process using conventional methods (Zawadzki, 2009 \& Villagonzalo, 2014)

There is a significant difference in learning outcomes between classes whose learning uses the free inquiry strategy and those that don't use the free inquiry strategy. The learning outcomes of students who learn through the free inquiry learning model are higher than the learning outcomes of students who learn through conventional learning models (Putri \& Nuriman 2012).

Students who use inquiry-based learning experience increased understanding and science process skills. Inquiry-based learning has a positive impact on students' conceptual understanding and scientific process skills (Põnarùimúek \& Kabapinar, 2010).

Education is a special recommendation that is very meaningful to provide opportunities for every student to learn creatively, grow and develop creatively and live creatively . Creativity is a spontaneous and imaginative mindset or idea that characterizes artistic results, scientific discoveries and creates new results, either completely new to the scientific or cultural world or relatively new to the individual himself even though other people have produced it before.

Creativity is a process carried out by a person, which causes him to create something new for him. "Creativity is a process that manifests it self in fluency, in flexibility as well in originality of thinking" (Langgulung, 2009). Creativity is a process that consists of: one, solving sensitive problems. Two, identifying difficulties. Three, investigation of settlement with certain references. Four, testing and retesting the hypothesis. Five, reporting the results. Creativity is not just a solution to a problem but includes all forms of thought that are focused on the production of ideas and ideas. Creativity is inseparable from divine origin. Human creativity is changing one form to 
another or a unit thought process that is based on flexibility and originality (Mulyasa, 2005).

Creativity is the ability to make new combinations or see new influences between elements, data or things that already exist. Creativity lies in the ability to see associations between things or objects that previously did not exist or had no visible influence. creativity is the forming of associative elements into new combination which either meet specified requirements or are in same ways useful. The more mutually remote the elements of the new combination, the more creative the process solution (Brickman, at.al. 2009.

Skills are the ability to use thoughts, reasoning and actions efficiently and effectively to achieve certain results, including creativity. Science (IPA) learning activities students should not only learn the concepts or products contained in the science (IPA) subject matter but must include other components, including the component of science process skills.

Science process skills are students' abilities to apply scientific methods in understanding, developing and discovering knowledge. Science process skills are also called a series of activities that can be measured from practicum activities. Science process skills in this study are in accordance with indicators of science process skills, namely: observing, grouping, predicting, asking questions, hypothesizing, planning experiments, using tools / materials, applying concepts, and communicating.

Science process skills are skills that are obtained from the training of basic mental, physical and social abilities as a driving force for higher abilities. The approach to process skills is described in teaching and learning activities paying attention to the development of knowledge of attitudes, values and skills. Process skills aim to improve the ability of students to realize, understand and master a series of activities related to the learning outcomes that students have achieved. The series of activities in question are activities to observe, classify, interpret, predict, implement, plan research, and communicate (Rustaman, 2009).

Process skills are a learning approach that emphasizes the learning process, activities and creativity of students in obtaining knowledge, skills, values and attitudes, and applying them in everyday life (Mulyasa, 2005). The process skills approach can be interpreted as an insight or role model for the development of intellectual, social and physical skills that come from the basic abilities that in principle already exist in students. The process skills approach to science learning emphasizes the formation of skills to acquire knowledge and communicate the results.

\section{RESEARCH METHODS}

This research uses a quantitative approach with an experimental design (Sugiyono: 2012). Quantitative research methods are based on the philosophy of positivism, used to research on specific populations or samples, data collection using research measuring instruments (instruments), quantitative / statistical data analysis, with purpose to test and prove the hypothesis that has been made / set. The experimental design was used with posttest only control group design which took two sample groups. The first group applied guided inquiry learning and the second group was the control group, namely the method of discussion, assignment and observation. The subject matter carried out in all classes is the same. From this group, it can be seen that creativity and science process skills. 
Table 1. Design Control

\begin{tabular}{|l|c|c|}
\hline \multicolumn{1}{|c|}{ Class } & Experiment & Test \\
\hline $\begin{array}{l}\text { Guide Inquiry } \\
\text { Experiment }\end{array}$ & $\mathrm{P} 1$ & $\mathrm{O} 1$ \\
\hline Control & $\mathrm{K}$ & $\mathrm{O} 2$ \\
\hline
\end{tabular}

This research was conducted at SMA Negeri 1 Bandar Baru, the research was conducted in the even semester of the 2019/2020 school year from February to June 2020.

The population in this study were all class XI students of the IPA program at SMA Negeri 1 Bandar Baru even semester of the 2019/2020 school year. In this study, two classes were in class XI. The sample was taken by using cluster random sampling.

The research process includes several stages, namely the preparation stage, the data collection stage, and the analysis stage. The preparation stage includes the stage of preparing learning tools such as syllabus, lesson plans (RPP), student worksheets (LKPD), observation sheets to measure science process skills and multiple choice questions for cognitive tests of student learning outcomes.

The data collection stage includes the stage of researching and testing the research instrument, where the researcher collects initial data in the form of students' cognitive test results before learning (pretest) in the experimental class and the control class. Posttest instrument in the form of multiple choice questions totaling 30 questions. The next meeting, the researcher carried out the teaching and learning process (PBM) in the experimental class with guided inquiry strategies and in the control class with conventional learning. At the fourth meeting after learning ended in the experimental class and the control class the researchers again collected data about science process skills and student learning outcomes. Data for learning outcomes (pretest) were collected using a test instrument in the form of 30 multiple choice questions. Data retrieval about students' science process skills was carried out using observation sheets in the student worksheet for practicum activities. The analysis stage is the processing of the results obtained from the data collection stage into quantitative data that is measured and processed using the SPSS 23.0 for windows application. Hypothesis testing in this study was carried out with parametric statistics using the Independent Sample t-Test.

Data collection techniques are tailored to the results to be achieved in the study. The instruments used in data collection were:

a. Creativity tests in the form of observation sheets and student self-assessments. This instrument aims to collect data about the level of creativity as research subjects.

b. Observation test of science process skills.

The research instrument before being used as a means of collecting data must meet certain requirements, namely validity and reliability. Validity is related to the accuracy of the assessment tool for the concept to be assessed so that it really assesses what should be assessed (Sudjana, 2009). 


\section{Science Process Skills Standards}

Observation is one of the basic process skills. Observation skills use five senses, namely sight, smell, touch, taste and listener. In the observation sheet analysis technique assessed are aspects of science process skills in the form of the check-list method. Observation sheets are used to describe students' science process skills during the learning process. The stages of analysis are as follows:

1. Sum the indicators from the observed PPP aspects

2. Calculating the percentage of PPP aspects in the group using the formula persentase $=\frac{\text { observation Risult Scor }}{\text { scor total }} \times 100 \%$

The data that has been obtained from the results of data analysis in the form of an observation sheet are then converted into percentage value categories and can be seen in the following table.

Tabel 2.

\section{Category Science Process Skills (KPS)}

\begin{tabular}{|c|c|}
\hline Persentase & Category \\
\hline $81-100$ & Very good \\
\hline $61-80$ & Good \\
\hline $41-60$ & Enough \\
\hline $21-40$ & Less \\
\hline $0-20$ & Very less \\
\hline
\end{tabular}

\section{RESEARCH RESULT}

The creativity score of each sample group will be categorized into high creativity and low creativity which is seen based on the average creativity score. Based on the grouping of the level of creativity in the experimental class and the control class, the average score of creativity for the experimental class is 62.33 and the control class is 55.00. The results of grouping

The percentage level of creativity for each indicator was higher in the experimental class. The indicator that has the highest percentage is curiosity of $82.22 \%$ in the experimental class and $71.11 \%$ in the control class, while the lowest is respect, namely $46.33 \%$ in the experimental class and $37.00 \%$ in the control class. . It can be concluded that students in the two dominant sample groups have curiosity than the other indicators and the least that students have is respect.

Student science process skills data were obtained through student assessment with observation sheets. The assessment was carried out on the LKPD practicum of disorders and disorders of the movement system in humans which was the last meeting of four learning meetings for the experimental class and the control class.

Hypothesis testing of the science process skills of the experimental class students applied inquiry strategy and the control class used conventional learning. Student science process skills data are shown in the following table. 
Table 3.

Description of the Science Process Skills data

\begin{tabular}{|c|c|c|c|c|c|}
\hline \multirow{2}{*}{ Treatment Class } & \multicolumn{3}{|c|}{ Nilai } & \multirow{2}{*}{ SD } & \multirow{2}{*}{ Varians } \\
\hline & High & Low & Avarage & & \\
\hline Control & 92,86 & 32,14 & 59,34 & 18,95 & 359,26 \\
\hline Eksperiment & 100 & 53,57 & 77,47 & 12,27 & 150,78 \\
\hline
\end{tabular}

The average observation of students' science process skills in the control class of SMA Negeri 1 Bandar Baru in the experimental class with a value of 61.95 and the control class with a value of 78.12. The highest score in the guided inquiry class and free inquiry was 100 and the lowest was 46.43, while in the control class the highest score was 92.86 and the lowest was 32.14.

Hypothesis testing in this study uses an average difference test of two samples. If there is a difference between the inquiry class and the control class, it means that there is an effect of guided inquiry strategies on science process skills.

Table 4

The Average Value of Students' Science Process Skills in the Classroom Experiment and Control Class

\begin{tabular}{|c|c|c|c|c|}
\hline Class & Average & Normality & Homogenity & Significance \\
\cline { 1 - 2 } Eksperiment & 77,79 & Sig $0,185>0,05$ & $\begin{array}{c}\text { Sig }(2 \text { tailed }) \\
0,583>0,05\end{array}$ & $\begin{array}{c}t \text { hit }>\text { t table } \\
6,055>1,98 \\
\text { Sig }(2-\text { tailed }) \\
0,000<0,05 \\
\text { Real Different }\end{array}$ \\
\hline
\end{tabular}

The $t$ test results showed that there was an influence on students' science process skills between the experimental class and the control class. This can be seen in Table 4, the significance column shows that t-count $>\mathrm{t}$-table at the significant level $\alpha=0.05$, is $6.055>1.98$, indicating that there is an effect of guided inquiry strategies on students' science process skills.

Science process skills have increased with the application of guided inquiry strategies. Students create their own hypotheses, plan experiments and communicate well between other groups and groups. Student cooperation is also seen, especially in the dynamics practicum, because in this material, cooperation is very much required to be able to work on all the sub-material of the practicum so that they get good results.

These results are supported and strengthened by the opinion of Brickman (2009) which states that students who use inquiry-based learning experience increased understanding and science process skills. Furthermore, Põnarùimúek (2010) states that inquiry-based learning has a positive impact on students' conceptual understanding and scientific process skills. 
The results of the study revealed several factors that became the basis for the effective use of inquiry strategies on students' science process skills. First, in the experimental class that uses an inquiry strategy, learning is directed at a learning process in terms of seeking and finding evidence of conclusions. Second, learning provides opportunities for students to work on a series of learning stages independently through worksheets that have been arranged in order to be able to reveal students' science process skills. Third, learning gives confidence to students to express their own ideas. This belief in one's own ideas creates a wide variety of ideas generated by students and increases the originality of each student's ideas.

Retno (2010) explains that the inquiry strategy will be effective if: (1) the teacher expects students to find answers to a problem themselves so that mastery of the material is not the main goal because the most important thing is the learning process, (2) the lesson material to be taught is in the form of conclusions that It needs proof, (3) the learning process departs from students' curiosity about something, (4) students are children who have the will and ability to think, (5) the number of students is not too much to be easily controlled, and (6) the teacher has a lot of time to take a student-centered approach.

\section{CONCLUSION}

The results showed that there was an influence on students' science process skills between the experimental class and the control class. It is shown that $\mathrm{t}$-count $>\mathrm{t}$-table at the significant level $\alpha=0.05$, namely 6.055> 1.98, indicating that there is an effect of guided inquiry strategies on students' science process skills. Science process skills of students who have a high level of creativity with students who have a low level of creativity, where students who have a high level of creativity obtain higher process skills than students who have a low level of creativity and between students' creativity and science process skills.

\section{Acknowledgement}

Thank you to the Minister of Research and Technology Republic of Indonesia for funding this research, and thanks to all those who have provided good support so that this research project was successful in accordance with predetermined targets.

\section{REFERENCES}

- Abdi, A. (2014). The Effect of Inquiry-based Learning Method on Students' Academic Achievement in Science Course. Universal Journal of Educational Research. 2 (1): 3741.

- Abubakar, A., \& Anwar, A. (2018). Analisis Materi Pendidikan Berkarakter dalam Pembelajaran Sosiologi pada SMA Kota Banda Aceh. Jurnal Serambi Ilmu, 22(1), 164-173.

- Bilgin, I. (2009). The Effects of Guided Inquiry Instruction Incorporatinga Cooperative Learning Approach on University Students' Achievement of Acid and Bases Concepts and Attitude Toward Guided Inquiry Instruction. Scientific Research and Essay. 4 (10). 1038-1046.

- Brickman, P., Gormally, C., Armstrong, N., \& Hallar, B. (2009). Effects of Inquirybased Learning on Students' Science Literacy Skills and Confidence. International Journal for the Scholarship of Teaching and Learning. Vol. 3, No. 2

- Dahar, R.W. (2011). Teori-Teori Belajar. Jakarta: Erlangga. 
- Deta, U.A. Suparmi, S. W. (2013). Pengaruh Metode Inkuiri Terbimbing dan Proyek, Kreativitas, serta Keterampilan Proses Sains terhadap Prestasi Belajar Siswa. Jurnal Pendidikan Fisika Indonesia (9) 28-34

- Hassard. J. (2010). The Art of Teaching Science: Inquiry and Innovation in Middle and High School. Oxford University Press. Oxford New York

- Israwati, I. (2018). Pengaruh Strategi Pembelajaran dan Motivasi Mengajar Guru Terhadap Hasil Belajar Siswa. Jurnal Serambi Ilmu, 19(2), 65-124.

- Junaidi dan Vera Wardani. (2019). Konteks Penggunaan Bahasa Tabu Sebagai Pendidikan Etika Tutur dalam Masyarakat Pidie. Jurnal Serambi Ilmu (20) 1, 1-17.

- Kholifudin, M. Y. (2012). Pembelajaran Fisika dengan Inkuiri Terbimbing Melalui Metode Eksperimen dan Demonstrasi Ditinjau dari Gaya Belajar Siswa. Prosiding Pertemuan Ilmiah XXVI HFI Jateng \& DIY, Purworejo ISSN: 0853-082.

- Langgulung, H. (2009). Beberapa Tinjauan dalam Pendidikan Islam. Kuala Lumpur. Pustaka Antara.

- Massialas, B.G. (2009). Discovery and Inquiry Methods. In A. Lewy (Ed). The international encyclopedia of curriculum. Oxford: Pergamon press PLC

- Muchsin \& Khumaedi. (2017) Analisis keterampilan mahasiswa calon guru dalam menjelaskan konsep menggunakan analogi pada pembelajaran Fisika. Jurnal Physics Communication. 1(1) 23-33

- Muchsin, Mariati (2020) Application of Project Based Learning Models in Improving Creative Thinking of Students at Physics Lessons in SMA Bandar Baru. Budapest International Research and Critics Institute-Journal. Volume3(2) 1453-1458

- Mudalara, I. P. (2012). Pengaruh Model Pembelajaran Inkuiri Bebas terhadap Hasil Belajar Kimia Siswa Kelas XI IPA SMA Negeri 1 Gianyar Ditinjau dari Sikap Ilmiah. Artikel. Universitas Pendidikan Ganesha.

- Mulyasa, E. (2005). Menjadi Guru Profesional Menciptakan Pembelajaran Kreatif dan Menyenangkan. Bandung: Remaja Rosdakarya

- Mulyasa, E. (2010). Menjadi Guru Profesional Menciptakan Pembelajaran Kreatif dan Menyenangkan. Bandung: Remaja Rosdakarya.

- Munandar, U. (2009). Kreativitas dan Keberbakatan. Jakarta: Gramedia Pustaka Utama

- Özdilek, Z. \& Bulunuz, N. (2009). The Effect of a Guided Inquiry Method on Preservice Teachers' Science Teaching Self-Efficacy Beliefs. Journal of Turkish Science Education. 6 (2).

- Põnarùimúek \& Kabapinar, N. (2010). The effects of inquiry-based learning on elementary students' conceptual understanding of matter, scientific process skills and science attitudes. Procedia Social and Behavioral Sciences. 2. 1190-1194

- Putri, A. M., Mahardika, I. K. \& Nuriman. (2012). Model Pembelajaran Free Inquiry (Inkuiri Bebas) dalam Pembelajaran Multirepresentasi Fisika di Man 2 Jember. Jurnal Pembelajaran Fisika, 1 (3) 324-327 
- Remziye. E., Ùø0ùeklø, Y., Çaliù, S., Özdølek, Z., Göçmençelebø, Ù. \& Ùanli, M. (2011). The Effects of Inquiry-Based Science Teaching on Elementary School Students' Science Process Skills and Science Attitudes. Bulgarian Journal of Science and Education Policy (BJSEP). 5 (1).

- Rustaman, N. (2009). Strategi Belajar Mengajar Biologi. Malang: UM Press

- Saleh, M., (2012), Pembelajaran Kooperatif Dengan Pendekatan Pendidikan Matematika Realistic (PMR), Jurnal Pendidikan Serambi Ilmu, 2 (13): 51 - 59.

- Sever, D. \& Güven, M. (2014). Effect of Inquiry-based Learning Approach on Student Resistance in a Science and Technology Course. Educational Sciences: Theory \& Practice. 14(4). 1601-1605

- Sudjana, N. (2009). Penilaian Hasil Belajar Mengajar. Bandung: Remaja Rosadakarya.

- Sugiyono. (2011). Metode Penelitian Pendidikan. Bandung. Alfabeta

- Trianto. (2010). Mendesain Model Pembelajaran Inovatif-Progresif. Jakarta: Kencana.

- Villagonzalo, E. C. (2014). Process Oriented Guided Inquiry Learning: An Effective Approach in Enhancing Students' Academic Performance. Presented at the DLSU Research Congress. De La Salle University, Manila, Philippines LLI-I-007

- Zawadzki, R. (2009). Is Process-oriented Guide-Inquiry Learning (POGIL) suitable as a teaching method in Thailand's higher education?. Educational Sciences: Theory \& Practice. 14(3).

Copyright (C) 2021 Muchsin, Hamdi. The manuscript open access article distributed under the Creative Commons Attribution License, which permits unrestricted use, distribution, and reproduction in any medium, provided the original work is properly cited. 